\title{
Arte e história da arte
}

\section{WALTER ZANINI}

$\mathrm{U}$ m longo tempo decorreu para que a USP demonstrasse interesse pelo ensino da arte. Os estatutos de 1934 previam uma escola específica que, entretanto, permaneceu letra morta. Décadas depois, em 1972, tomaria forma - finalmente - uma área prático-teórica, ainda hoje parte do conglomerado de departamentos da ECA. Mas as tentativas de configurar esse território em toda a sua complexidade - nos projetos de criaçáo de um instituto de arte - encontraram sempre muitos obstáculos e não se concretizaram.

No que concerne propriamente à História da Arte - disciplina de antiga trajetória nas naçōes européias, embora não estabelecida em suas universidades antes das últimas décadas do século XIX - seu ingresso na USP deu-se através de improvisaçóes, até uma sua relativa consolidação que se deu recentemente.

Seriam os professores Lévi-Strauss, Roger Bastide e Jean Maügué a trazer nos anos $\mathbf{3 0}$ um impulso introdutório aos estudos da arte junto aos alunos de suas áreas da FFCL, como a esse respeito se refere a professora Gilda de Mello e Souza (1).

Posteriormente, na década de 50, o professor Lourival Gomes Machado, catedrático de ciência política e estudioso das artes, particularmente do barroco brasileiro, mas com desempenho também na crítica da arte contemporânea, lecionou a História da Arte na Faculdade de Arquitetura e Urbanismo da USP, adaptada às finalidades da escola, na qual, a partir de 1962, seria ministrada junto ao Departamento de História da Arquitetura e Estética do Projeto, tendo como seu primeiro docente $o$ artista e professor Flávio Motta.

Um maior aprofundamento foi alcançado pela disciplina no Departamento de História da FFCL, desde o começo da década de 60 , cabendo inicialmente ao professor Yves Bruand, diplomado pela École de Chartes e responsável pelas áreas de Metodologia e Teoria da História e Paleografia, ministrar aulas em curso optativo. Entre 1962 e 1969, tivemos a responsabilidade da cadeira, assistida por turmas crescentes de estudantes. Detivemo-nos particularmente nas etapas artísticas entre o 
humanismo renascimental e a arte moderna, dando porém atenção a problemas de método da historiografia artística e a elementos de museologia. Em 1968, o Departamento de História implantou o primeiro curso de História da Arte em nível de pós-graduação no país.

Como conseqüência da reforma universitária, o Departamento de História perdeu a disciplina (1970), transferida para os organogramas da ECA. Em compensação, a História da Arte ganhou desenvoltura na escola recém-fundada, onde se criou o curso de Educação Artística em 1972 , sendo de relevar que o mestrado inaugurado no Departamento de História, foi por sua vez herdado pela ECA nesse ano. Mais adiante, em 1980, surgiria na mesma unidade o doutorado (ainda hoje único na universidade brasileira). O Departamento de Artes Plásticas tornou-se a célula de outros cursos de pós-graduaçáo em arte no Brasil.

Elemento da mais alta importância a considerar no espaço ganho pelas artes na USP é a introdução de coleçôes de arte e arqueologia nos anos 60, na gestão de Ulhôa Cintra. Além do fato em si do que representam esses acervos relevantes, no que diz respeito ao ensino e à difusão da arte e dos estudos arqueológicos (instalados na USP na década de 60), sua presença tem sido de inestimável valor para cursos das mais variadas naturezas no decorrer dos últimos 30 anos. $O M A C$ e o $\mathrm{MAE}$, aos quais se acrescenta o IEB, formam um tripé nesse sentido, incluindo-se os serviços de orientaçáo pedagógica que prestam no atendimento ao público em geral.

Discorrendo em termos mais gerais, é necessário lembrar que o ensino da História da Arte fora instituído no Brasil pela Academia Imperial das Belas Artes e ministrado a partir de 1890, mas em limites dos mais precários, até que se encontrasse melhor estrutura junto à Universidade do Brasil (1931). O ensino prático-teórico da velha academia do Rio de Janeiro irradiou-se para outras escolas de belas artes do país, a começar da Bahia. Com a criaçáo dos cursos de licenciatura em educação artística (1970), a História da Arte permaneceu dirigida fundamentalmente para a formação de artistas. Para os que almejavam maiores conhecimentos teóricos e históricos, o que lhes reservava a malha de ensino era escasso (como acontece ainda hoje). Aos poucos, os professores credenciados pela formação e obtenção de títulos em universidades estrangeiras de grande tradição na disciplina (na Sorbonne, do mais alto nível e do maior rigor antes da reforma do fim dos anos 60) e os que realizaram mestrado e doutorado no país (desde o decênio de 70) a partir da USP - constituíram um corpus de historiadores que hoje conta com algumas dezenas de indivíduos sobre os quais repousa boa parte da responsabilidade da pesquisa e do ensino da arte e sua história 
no Brasil. Seus trabalhos têm-se voltado geralmente para a arte do entorno, em seus diversificados períodos: época colonial, século XIX (da Missão Artística Francesa a Elíseu Visconti) e Modernidade.

Em que pese a etapa ganha com a criação da ECA, náo se possui ainda hoje um instituto de arte na USP, aspiração legítima que encontra o empecilho de outros interesses, e que é uma frustração para todos os que pensam seriamente no assunto. A História da Arte, disciplina básica e indispensável dessa área da cultura, não dispóem até hoje de um bacharelado ou licenciatura. É matéria exigida para os polivalentes cursos de educação artística. Figura nos currículos das faculdades de arquitetura e urbanismo com objetivos dirigidos à sua especificidade e é matéria opcional para cursos de filosofia, letras, ciências sociais, comunicaçóes, entre outros. Prestando serviços a todos, mantém-se no entanto a disciplina sem a definição de seu próprio campo de graduação.

Razóes complexas levaram primeiro à instituição dos cursos de pós-graduação, para o que concorreu a existência de professores titulados no exterior, ao passo que não se estabeleceu o curso básico. Outros problemas que continuam afligindo a área resumem-se à falta de bibliotecas importantes e à grande precariedade da documentação iconográfica.

A História da Arte foi introduzida no Brasil na observância dos princípios e métodos gerados na ordenaçáo da disciplina na Europa, a partir de Burckhardt e Morelli, e sua situação, entre os pólos diferenciados do velho mundo e dos Estados Unidos, é ainda a de um domínio de estudos emergentes que se exerce em contextos humano e histórico peculiares neste continente. Absolutamente isso significa que o trabalho em curso, há algumas décadas, não tenha produzido resultados substanciais sobre a arte do próprio meio. Se essa atividade relativa ao território exigirá muito ainda, a disciplina, por outro lado, deverá evoluir para estágios que fortaleçam o seu profundo sentido universal. Náo deverá faltar aqui a contribuição da USP.

Nota

1 A Estética rica e a estética pobre dos professores franceses. Discurso, no 9, São Paulo, nov. 1978, p. 9-30.

Walter Zanini é professor do Departamento de Artes Plásticas da Escola de Comunicaçóes e Artes da USP. 